\title{
POTATO BY - PRODUCTS AS ANIMAL FEED : 4 - EFFECT OF SOLANINE ON MINERALS AND VITAMINS IN SHEEP DIETS .
}

\author{
Saleh, M. R. M.; A. A. Abd El- Aziz and G. I. Elemam
}

Animal Production Res. Institute, Agric. Res. Center, Dokki, Egypt .

\begin{abstract}
The objective of the present study was to assess the potential effects of solanine in potato by-products ( PB-P) on minerals and vitamins utilization and nitrogen retaintion. Nine Rahmany rams at 3 years of age, $70.35 \mathrm{~kg}$ body weight devided into three groups three animals each their assigned to three digestion trials with three experimental rations. The experimental diets were consists of $50 \%$ concentrate feed mixture (CFM) $+50 \%$ roughage as well as berseem hay in control ration, potato by-products silage (PB-PS) and potato by-products hay (PB-PH) in second and third rations, respectively. The results indicated that the DMI of potato by - products silage ( PB-PS ) was higher than another tested treatments. Daily solanine dose is higher $(p<0.05)$ in potato by - products hay (PB-PH) compared to PB-PS group. Some measures were taken on rations, blood, faeces and urine to determine the minerals and vitamins quantites. The results showed that the nitrogen intake was lower in BP-PH than control and BP-PS. Whereas nitrogen excretion was the highest in control and BP-PH groups than BP-PS group and the diffrences were significant $(p<0.05)$. However, nitrogen balance was higher with BP-PS ration more than another expermintal groups. The minerals as well as calcium, phophorus, magnisium, sodium, iron, manganis, zink and potasium were significantly $(p<0.05)$ higher in PB-PS compared to PB-PH and control group , excepet for the potassium intake in was lower in PB-PS than other test groups, these results was almost similler to those obtained in blood serum. Howeve, the mineral balance as well as, calcium , magnisium, sodium, iron, manganis, zink and potasium of PB-PS were significantly $(\mathrm{p}<0.05)$ higher than those of PB-PH and control diets. Whereas it was lower in phosphorus content copared to PB-PH group. The mineral intake as well as calcium, phophorus, magnisium, sodium, manganis, zZink and potasium were significantly $(\mathrm{p}<0.05)$ lower in PB-PS than another groups, except of iron is higher in PB-PS than others. Whereas minerals balance of PB-PH were higher significantly $(p<0.05)$ in magnisium, zink and potasium than PB-PS, but it was lower in another elements. The results indicated that the vitamins intake as well as B1, B3, B6 and C are significantly $(\mathrm{p}<0.05)$ lower in PB-PS, except B2 is higher, than PB-PH and control groups. Serum blood of PB-PS were significantly $(p<0.05)$ lower of all vitamins, except of vitamine B3 is higher. All vitamins serum blood of control group were significantly $(p<0.05)$ higher than other groups .
\end{abstract}

Keywords : Solanine, Minerals, Rahmany rams, Potato by-products, Silage, and Hay

\section{INTRODUTION}

Potato contains a number of important minerals and vitamins . hundred and fifty gm of potato provides $27 \mathrm{mg}$ vitamin $\mathrm{C}, 620 \mathrm{mg}$ of potassium , 0.2 $\mathrm{mg}$ vitamin $\mathrm{B} 6$ and trace amounts of thiamin, riboflavin, folate, niacin , magnesium, phosphorus, iron, and zinc.In addition, potato also contains an assortment of phytochemicals, such as carotenoids and polyphenols. Such potato by products offer an excellent feed source in nutrition ( Gull et al ., 1970 ). Peeled, long - stored potatoes have less nutritional value, although 
they still have potassium and vitamin B . Low fecal excretions of calcium, magnesium, phosphorus, and sulfur resulted in positive balances for these minerals .Calcium balance was more positive when subjects received the pinto bean diet, which also supplied more lysine and calcium than the other diets. Abd El hamid et al ., ( 1999 a and b ) reported that Zariby goats had being $8.13-8.29 \mathrm{mg} \mathrm{Ca} / \mathrm{dl}, 3.45-4.31 \mathrm{mg} \mathrm{P} / \mathrm{dl}, 2.69-3.63 \mathrm{mg} \mathrm{Mg} / \mathrm{dl}$ and $60.8-96.2 \mu \mathrm{g} \mathrm{Fe} / \mathrm{dl}$. It is suggested that one aspect of the mechanism of metabolic adjustment to low protein intake involves greater contain glycoalkaloids, toxic compounds, of which the most prevalent are solanine at high temperatures (over $170{ }^{\circ} \mathrm{C}$ ) partly destroys these. Glycoalkaloids retention of dietary sulfur, greater conservation of absorbed sulfur, and a reduction in the catabolism of sulfur-containing amino acids.( Edward et al ., 1972 ). Potatoes occur in the greatest concentrations just underneath the skin of the tuber, stem and they increase with age and exposure to light . Solanine may cause headaches, diarrhea, cramps and in severe cases coma and death. However, poisoning from potatoes occurs very rarely. Light exposure also causes greening. Breeders try to keep solanine levels below 2 $\mathrm{mg} / \mathrm{kg}$ body weight. The National Toxicology Program suggests that the average american consumes at most $12.5 \mathrm{mg} /$ person/day of solanine from potato . Saleh et al. ( 2007 ) found that solanine in potato by-products had effective harmfull and toxicity effects. However,feeding common potato led to solanine toxicity and affected performance of starter, growing and finishing pigs ( Patil et al .,1972) . Jadhav et al .(1981) found natural occurring toxic alkaloids in potatoes by - products . Morris and Lee (1984) and Renwick et al . (1984 )detected solanine emberyotoxicity and teratogenicity, as well as inhibition of rat cholinesterase isoenzymes in vitro and in vivo by the potato alkaloid. Alozie et al . (1978) found that the amount of solanine was about 0 . $01-0.1 \%$ of potatoes dry matter . Solanine is also found in other plants, including the potato and dangerous plants like tobacco.

The main objective of the present study was aimed to investigate the harmfull effect of solanin in potato by -products silage (PB-PS) and potato by- products hay (PB-PH) on minerals and vitamins utilization .

\section{MATERIALS AND METHODS}

This experiment was carried out in El - Serw Animal Production Research Sation, Animal Production Research Institute, Agriculture Research Center, through the year 2005. Aimed to envestigate the effect of solanine in potato by - products on minerals and some vitamins utilization . Three treatments with three rims in each with an average body weight of 70 . $35 \mathrm{~kg}$ and 3 years of age were used in this study. Rams were housed in groups and kept under shade. The feeding system was $50 \%$ concentrate + $50 \%$ roughage, as berseem hay in $\mathrm{CB}$ or potato by product in the form $\mathrm{PB}$ PS and PB-PH. The PB-PS is consists of potato vine, greenish spots and small damage tubers which, supplememted with $5 \%$ molasses $+3 \%$ urea . Feed was offered twice daily at $8 \mathrm{am}$ and $3 \mathrm{pm}$. Feed intake and faeces weight were recorded and collected daily in plastic bags from each ram .The collection period was 7 days following a 2 -weeks as preliminary period. 
Urine was measured daily and collected after diluted with $20 \mathrm{ml}$ of conc.sulfuric acid to kept ammonia until nitrogen determination. Minerals were determined in feed, faeces and urine. Amino acids were determined in feeds also. The solanine was determined quantitively in potato silage, potato hay, faeces and urine .

\section{Chemical analysis :}

Composite samples were prepared for chemical analysis. Faeces samples were analyzed according to A.O.A.C ( 2000 ). Minerals as well as Ca was determined according to Elvebach ( 1970), P according to Freidman et al ., 1980 ) , Mg according to Oranye and Rhein ( 1951 ) and Iron according to Meites (1977). Whereas the vitamins were determined according to A.O.A.C. (2000). Amino acids were determined by amino acid analyzer at Food and Feed Laboratory Center according to Kofranyi and Jekat (1964). Solanine was determined according Bushway and Ponnampalam (1985) . Statistical analysis:

Data were analyzed using the general linear model procedure of SAS (1996). The significant differences among means were determined by the new multiple rang test ( Duncan ,1955).

\section{RESULTS AND DISCUSSION}

Chemical analysis and nutritive values of rations, solanine and amino acids are presented in Table (1).

Table 1 : Chemical analysis of feed ingredients and experimental Rations, nutertive values and solainin e content in ration fed by Rahmany rams (\%on dry matter basis ) .

\begin{tabular}{|c|c|c|c|c|c|c|c|}
\hline Item, \% & DM & OM & CP & CF & EE & ASH & NFE \\
\hline \multicolumn{8}{|c|}{ feed ingredients } \\
\hline CFM & 90.13 & 89.70 & 14.88 & 13.40 & 3.10 & 10.30 & 58.92 \\
\hline CB & 88.58 & 89.22 & 13.94 & 14.09 & 2.85 & 10.78 & 58.34 \\
\hline PB-PS & 87.34 & 90.24 & 12.30 & 11.48 & 3.46 & 9.76 & 63.00 \\
\hline $\mathrm{PB}-\mathrm{PH}$ & 89.72 & 89.57 & 11.59 & 17.55 & 2.76 & 10.43 & 57.76 \\
\hline \multicolumn{8}{|c|}{ Nutritive values } \\
\hline & & & \multicolumn{2}{|c|}{ Control } & \multicolumn{2}{|l|}{ PB-PS } & $\overline{\mathrm{PB}-\mathrm{PH}}$ \\
\hline \multicolumn{3}{|c|}{ DMI ( $\mathrm{kg} / \mathrm{h} / \mathrm{d})$} & \multicolumn{2}{|c|}{$2.68 b$} & \multicolumn{2}{|l|}{$2.85 a$} & $2.79 \mathrm{~b}$ \\
\hline \multicolumn{3}{|c|}{$\operatorname{TDN}(\mathrm{g} / \mathrm{h} / \mathrm{d})$} & \multicolumn{2}{|c|}{62.78} & \multicolumn{2}{|l|}{65.43} & 63.21 \\
\hline \multicolumn{3}{|c|}{$\operatorname{DCP}(g / h / d)$} & \multicolumn{2}{|c|}{11.25} & \multicolumn{2}{|l|}{11.20} & 10.53 \\
\hline \multicolumn{3}{|c|}{ Water consumption $(\mathrm{g} / \mathrm{h} / \mathrm{d})$} & \multicolumn{2}{|c|}{$3250 \mathrm{c}$} & $2870 a$ & & $3510 b$ \\
\hline \multicolumn{8}{|c|}{ Solanine content $(\mathrm{mg} 1 / 00 \mathrm{gm})$} \\
\hline & & & \multicolumn{3}{|c|}{ PB-PS } & \multicolumn{2}{|c|}{ PB-PH } \\
\hline \multicolumn{3}{|l|}{ Diet } & \multicolumn{3}{|c|}{$133.88 b$} & \multicolumn{2}{|c|}{$382.51 \mathrm{a}$} \\
\hline \multicolumn{3}{|l|}{ Faeces } & \multirow{2}{*}{\multicolumn{2}{|c|}{$\frac{39.80 b}{28.47 b}$}} & & \multicolumn{2}{|c|}{$71.93 a$} \\
\hline \multicolumn{3}{|l|}{ Urine } & & & & \multicolumn{2}{|c|}{$58.21 a$} \\
\hline
\end{tabular}

Means having different superscripts within the same row are significantly different at $P<0.05$.

CFM = concentrate feed mixture , PB-PS = potayo by -products silage , PB-PH = potayo by -products hay 
Amino acid content :

Amino acids \% in rations are presented In Table (2), the results clearly that PB-PS was higer of amino acids than PB-PH and control groups .

Table 2 : Amino acids conten(\%) in the experimental rations .

\begin{tabular}{|l|c|c|c|}
\hline \multirow{2}{*}{ Amino acid } & \multicolumn{3}{|c|}{ Expermintal diets } \\
\cline { 2 - 4 } & Control & PB-PS & PB-PH \\
\hline Alanine & 4.10 & 4.56 & 3.90 \\
\hline Argnine & 3.70 & 4.29 & 2.00 \\
\hline Aspartic acid & 5.30 & 18.78 & 4.40 \\
\hline Cystine & 0.50 & 4.93 & 0.70 \\
\hline Glutamic acid & 9.15 & 12.10 & 11.40 \\
\hline Glycine & 4.55 & 4.12 & 3.80 \\
\hline Histiden & 1.10 & 1.97 & 1.20 \\
\hline Leucine & 7.23 & 5.24 & 3.10 \\
\hline Iso leucine & 4.37 & 4.86 & 2.60 \\
\hline Lysine & 0.60 & 3.42 & 1.60 \\
\hline Methionine & 2.20 & 2.33 & 3.00 \\
\hline Phenyle A. & 3.71 & 5.11 & 3.80 \\
\hline Praline & 1.05 & 2.03 & 0.40 \\
\hline Serine & 1.50 & 2.19 & 1.10 \\
\hline Therionine & 0.26 & 2.31 & 0.40 \\
\hline Treptophane & 4.17 & 3.70 & 5.30 \\
\hline Tyrosine & 1.60 & 2.09 & 1.30 \\
\hline Valine & 4.98 & 5.85 & 4.50 \\
\hline
\end{tabular}

\section{Nitrogen retaintion :}

Results of nitrogen retention of rams fed on expermintal rations is presented in Table (3) . Nitrogen intake was lower in BP-PH than control and BP-PS groups. Nitrogen balance was higher with BP-PS ration more than another expermintal groups. Resulats indcated that silage process improved nitrogen balance as a percentage of intake $(29.43,21.46$ and $21.41 \%$ for BP-PS , BP-PH and control, respectively ). This result is agreement with the finding of Saleh et al. (2007a) .

Table ( 3 ) : Nitrogen balance of rams fed on potato by - products silage or hay.

\begin{tabular}{|l|c|c|c|}
\hline Items & Control & PB-PS & PB-PH \\
\hline Nitrogen balance mg / kg BW & $850 \mathrm{a}$ & $802 \mathrm{~b}$ & $736 \mathrm{c}$ \\
\hline Total nitrogen excretion mg / kg BW & $668 \mathrm{a}$ & $566 \mathrm{~b}$ & $587 \mathrm{c}$ \\
\hline Digestable nitrogen mg / kg BW & $528 \mathrm{a}$ & $525 \mathrm{a}$ & $462 \mathrm{~b}$ \\
\hline Nitrogen balance mg / kg BW & $182 \mathrm{a}$ & $236 \mathrm{a}$ & $149 \mathrm{~b}$ \\
\hline Nitrogen balance of Nitrogen balance \% & $21.41^{\mathbf{b}}$ & $29.43 \mathrm{a}$ & $21.46^{\mathbf{b}}$ \\
\hline
\end{tabular}

means in the same rows were superscripted by differletter significantly $(P<0.05)$.

\section{Minerals intake :}

Data in Table (4) indicated that minerals intake had variation values and significant diffrences among treatments, particularly was the poptato by products silage ( PB-PS ). It had significantly $(\mathrm{p}<0.05)$ higher intake in all tested minerals than those of control $(\mathrm{CB})$ and potato by-products hay (PB- 
$\mathrm{PH})$, except of potassium in potato by-products hay group which was significantly $(p<0.05)$ higher when compared to other groups. These results may be due to molasses supplemented to silage through the silage making or to the increase of solanine level in PB-PH diet .

Table ( 4 ). Minerals intake $\mathrm{mg} / \mathrm{h} / \mathrm{d}$ of exprrimental diets of rams fed on potato by - products as silage or hay.

\begin{tabular}{|l|c|c|c|}
\hline \multicolumn{1}{|c|}{ Items } & Control & PB-PS & PB-PH \\
\hline Calcium & $4788.4 \mathrm{~b}$ & $5630 \mathrm{a}$ & $4452 \mathrm{~b}$ \\
\hline Phophorus & $3015.5 \mathrm{~b}$ & $3782 \mathrm{a}$ & $2867 \mathrm{c}$ \\
\hline Magnisium & $3359.2 \mathrm{~b}$ & $3867 \mathrm{a}$ & $3241 \mathrm{~b}$ \\
\hline Sodium & $5376.0 \mathrm{~b}$ & $6738 \mathrm{a}$ & $4298 \mathrm{c}$ \\
\hline Iron & $2432.7 \mathrm{~b}$ & $4753 \mathrm{a}$ & $1730 \mathrm{c}$ \\
\hline Manganis & $720.3 \mathrm{~b}$ & $911 \mathrm{a}$ & $531 \mathrm{c}$ \\
\hline Zink & $170.5 \mathrm{~b}$ & $217 \mathrm{a}$ & $180 \mathrm{~b}$ \\
\hline Potasium & $215.4 \mathrm{~b}$ & $447 \mathrm{~b}$ & $490 \mathrm{a}$ \\
\hline
\end{tabular}

Means having different superscripts within the same row are significantly different at $\mathbf{P}<$ 0.05 .

\section{Blood minerals :}

The results clearly that minerals in blood as well as calcium , phophorus, magnisium, sodium, iron, manganis, zink and potasium in PB-PS were significantly $(p<0.05)$ higher than PB-PH and control group, except of potassium intake whch was lower in PB-PS than other groups. Abdelhamid et al ., ( $1999 \mathrm{a} \& \mathrm{~b}$ ) reported nearly similar values for Zaribi goats .

Table ( 5 ) . Some minerals $(\mathrm{mg} / 100 \mathrm{ml})$. in blood of rams fed on potato by - products Silage or hay treatment.

\begin{tabular}{|l|c|c|c|}
\hline Blood minerals & Control & PB-PS & PB-PH \\
\hline Calcium & $9.62 \mathrm{~b}$ & $10.21 \mathrm{a}$ & $8.04 \mathrm{~b}$ \\
\hline Phosphorus & $5.48 \mathrm{~b}$ & $7.66 \mathrm{a}$ & $4.21 \mathrm{~b}$ \\
\hline Iron & $79.51 \mathrm{~b}$ & $98.78 \mathrm{a}$ & $81.35 \mathrm{~b}$ \\
\hline Magnesium & $3.92 \mathrm{~b}$ & $4.38 \mathrm{a}$ & $5.06 \mathrm{a}$ \\
\hline Sodium & 9.85 & 12.79 & 10.41 \\
\hline Manganis & 2.18 & 2.57 & 2.98 \\
\hline Zink & 1.76 & 1.34 & 1.85 \\
\hline Potasium & 7.38 & 8.97 & 10.44 \\
\hline
\end{tabular}

Means in the same rows were superscripted by different letters significantly $(P<0.05)$.

\section{Minerals excretion :}

The faeces and urine minerals are presented in Table ( 6 ). Results showed that minerals excretion of PB-PS significantly $(p<0.5)$ higher when compared with those obtained from PB-PH and control group. While minerals excretion of PB-PH group was significantly lower $(p<0.05)$ than PB-PS and control one , except for total potassium excretion in PB-PH was more higher than PB-PS and control group. These results agreed with Hoek et al ., ( 1988 ) who reported that calcium concentration, calcium : phosphorus (Ca: $P$ ) ratio and magnesium were effecte on mineral balance. The urinary 
excretion of $\mathrm{P}$ decreased with increasing dietary $\mathrm{Ca}$ and increased with increasing $P$ intake in rats .

Table (6) . Mineral excretion in faeces and urine of Rahmany rams fed on potato by- products as silage or hay, $\mathrm{mg} / \mathrm{h} / \mathrm{d}$.

\begin{tabular}{|c|c|c|c|c|}
\hline & & Control & PB-PS & PB-PH \\
\hline Calcium & Faeces & $2059 b$ & 2533a & $1825 c$ \\
\hline & Urine & $50 b$ & $64 a$ & $50 b$ \\
\hline Phophorus & Faeces & $1296 b$ & $1672 a$ & $1031 c$ \\
\hline & Urine & $35 a$ & $31 b$ & $30 b$ \\
\hline Magnisium & Faeces & $1481 b$ & $1764 a$ & $1450 \mathrm{~b}$ \\
\hline & Urine & $38 b$ & $40 a$ & $35 c$ \\
\hline Sodium & Faeces & $2296 b$ & $3005 a$ & $1801 \mathrm{c}$ \\
\hline & Urine & $58 a$ & $62 a$ & $44 b$ \\
\hline Iron & Faeces & 1050b & $2106 a$ & $975 c$ \\
\hline & Urine & $28 b$ & $51 a$ & $21 b$ \\
\hline Manganis & Faeces & $188 b$ & $316 a$ & $134 c$ \\
\hline & Urine & $27 b$ & $38 \mathrm{a}$ & $19 c$ \\
\hline Zink & Faeces & $58 a$ & $69 a$ & $37 b$ \\
\hline & Urine & $12 b$ & $16 a$ & $11 b$ \\
\hline Potasium & Faeces & $59 b$ & $87 a$ & $70 b$ \\
\hline & Urine & $15 b$ & $20 a$ & $15 b$ \\
\hline
\end{tabular}

Means having different superscripts within the same row are significantly different at $\mathrm{P}<0.05$

\section{Minerals balance :}

Calcium , magnisium , sodium , iron , manganis , zink and potasium balances for PB-PS group were significantly $(p<0.05)$ higher than those of PB-PH and control diets, whereas it was significantly lower in phosphorus when compared to PB-PH group. On the other hand the \% of minerals intake as calcium, phophorus , magnisium, sodium, manganis, zink and potasium were significantly $(p<0.05)$ lower in PB-PS than another groups, except of iron was higher in PB-PS than others. Whereas minerals balance of PB-PH were higher significantly $(p<0.05)$ of Magnisium, zink and Potasium than PB-PS and lower in another elements (Table, 7) .The results are in agreement with Hoek et al ., ( 1988 ) .

\section{Vitamins in diets and blood :}

Data in Table ( 8 ) clearly showed that intake of vitamin B1 ( thiamin), B3 ( cicine), vitamin. 6 and vitamin . C of control group was significantly $(\mathrm{p}<0.05)$ higher compared to PB-PS and PB-PH groups, whereas the same group is lower in riboflavin (Vit. B2). This result indicated that vitamin B1 is affected by level of solanine in diet .This is agrees with Saleh et al ., ( 2007 ) who reported that the solasnine in potatoes by products is more harmfull effects on both humen and animals. Also, the results indicated clearly that PB-PS is higher in its contain of riboflavin (Vit. B2). Saimillar result was obtained to Vitamin C . While PB-PS was significantly $(p<0.05)$ higher in all vitamins than PB-PH group . 
Table ( 7 ) . Mineral balance , $(\mathrm{mg} / \mathrm{h} / \mathrm{d})$ and $\%$ of intake of rams fed potato by- products as silage or hay .

\begin{tabular}{|c|c|c|c|c|}
\hline \multicolumn{2}{|l|}{ Items } & Control & PB-PS & PB-PH \\
\hline \multirow[t]{2}{*}{ Calcium } & Balance & $2680 b$ & $3033 a$ & $2577 b$ \\
\hline & $\%$ of intake & $56 a$ & $54 b$ & $58 a$ \\
\hline \multirow[t]{2}{*}{ Phophorus } & Balance & $1684 b$ & $2079 a$ & $1806 b$ \\
\hline & $\%$ of intake & $56 b$ & $55 b$ & $63 a$ \\
\hline \multirow[t]{2}{*}{ Magnisium } & Balance & $1840 c$ & $2063 b$ & $2115 a$ \\
\hline & $\%$ of intake & $55 b$ & $53 b$ & $62 a$ \\
\hline \multirow[t]{2}{*}{ Sodium } & Balance & $3022 c$ & $3672 a$ & $2453 b$ \\
\hline & $\%$ of intake & $56 a$ & $55 b$ & $57 a$ \\
\hline \multirow[t]{2}{*}{ Iron } & Balance & $1353 b$ & $2597 a$ & $734 c$ \\
\hline & $\%$ of intake & $56 a$ & $55 a$ & $42 b$ \\
\hline \multirow[t]{2}{*}{ Manganis } & Balance & $507 a$ & $557 a$ & $377 b$ \\
\hline & $\%$ of intake & $70 a$ & $61 \mathrm{~b}$ & $71 a$ \\
\hline \multirow[t]{2}{*}{ Zink } & Balance & 110b & $132 a$ & $132 a$ \\
\hline & $\%$ of intake & $65 b$ & $624 c$ & $74 a$ \\
\hline \multirow[t]{2}{*}{ Potasium } & Balance & $142 b$ & $340 a$ & $355 a$ \\
\hline & $\%$ of intake & $66 c$ & $76 b$ & $82 a$ \\
\hline
\end{tabular}

Means having different superscripts within the same ro are significantly different at $P<0.05$.

Table ( 8 ) . Some vitamins in diets and blood $\mathrm{mg} / 100 \mathrm{gm}$ or1 $\mathrm{ml}$. of rams fed on PB-PS and PB-PH $\mathrm{mg} / 100 \mathrm{gm}$

\begin{tabular}{|l|c|c|c|c|}
\hline Items & & Control & PB-PS & PB-PH \\
\hline \multirow{2}{*}{ Thiamin (Vit. B1) } & diets & $2314.3 \mathrm{a}$ & $2712.4 \mathrm{~b}$ & $1998.7 \mathrm{c}$ \\
\cline { 2 - 5 } & Blood & $24.58 \mathrm{a}$ & $19.33 \mathrm{~b}$ & $14.98 \mathrm{c}$ \\
\hline \multirow{2}{*}{ Niacin (Vit. B3) } & diets & $0.43 \mathrm{c}$ & $0.67 \mathrm{a}$ & $0.59 \mathrm{a}$ \\
\cline { 2 - 5 } & Blood & $0.091 \mathrm{a}$ & $0.078 \mathrm{~b}$ & $0.053 \mathrm{c}$ \\
\cline { 2 - 5 } & diets & $34.7 \mathrm{a}$ & $23.39 \mathrm{~b}$ & $26.16 \mathrm{~b}$ \\
\hline \multirow{2}{*}{ Vitamin B6 } & Blood & $8.49 \mathrm{a}$ & $7.21 \mathrm{~A}$ & $5.69 \mathrm{~b}$ \\
\cline { 2 - 5 } & diets & $8.26 \mathrm{a}$ & $6.35 \mathrm{~b}$ & $5.03 \mathrm{~b}$ \\
\hline \multirow{2}{*}{ Vitamin C } & Blood & $2.94 \mathrm{a}$ & $1.67 \mathrm{~b}$ & $1.49 \mathrm{~b}$ \\
\cline { 2 - 5 } & diets & $653.4 \mathrm{a}$ & $595.6 \mathrm{~b}$ & $488.6 \mathrm{c}$ \\
\cline { 2 - 5 } & Blood & $13.58 \mathrm{a}$ & $10.69 \mathrm{~b}$ & $8.11 \mathrm{~b}$ \\
\hline
\end{tabular}

Means having different superscripts within the same row are significantly different at $P<0.05$.

\section{CONCLUSION}

This study indicated that minerals in potato by-products silage or hay were significantly affected by solanine in diets.

\section{REFERENCES}

Abd El hamid, M. A ; E.I .Shehata and M.E . Ahmed ( 1999 a ). Physio nutritional studies on pregnant and lactating goats fed on rations deffering in roughage/ concentrate ratio2 -Effect on blood profile. J.Agric. Sci. Mansoura Univ. , 24 : 4587-04612 
Abd El hamid, M. A ; E.I Shehata and M.E. Ahmed ( 1999 b ). Physionutritional studies on pregnant and lactating goats fed on rations deffering in roughage / concentrate ratio 3 - Effect on productivity and digestion . J.Agric. Sci. Mansoura Univ. , $24: 4587-04612$.

Alozie, S.O., R.P. Sharma and D.K. Salunkhe (1978). Inhibition rat Cholinesterase isoenzymes in vitro and in vivo by the potato glycoalkaloid ( alpha-solanine and alpha caconine ). J. Food Biochem., 2: 259-276.

A.O.A.C. (2000).Association of Official Analytical Chemsts Official Methods of Analysis, $17^{\text {th }}$ ed. Washington, D.C.

Bushway, R.J. and R. Ponnampalam (1985). Alpha-solanine content of potato products . J. Agric. Food Chem., 34: 277 - 279.

Duncan , D .B .(1955) .Maltiple range and multiple F-test . Biometrics ,11:1 $-42$

Edwards , H. K .Lovie ; M .S. Booker ( 1972). Utilization of wheat by adult man : excretion of vitamins and minerals. American Journal of Clinical Nutrition, 24: 547-555,

Elvebach , I.R. ( 1970 ) Method of calcium determination in foods and feed J.Am . MED. Ass., 211- 69

Freidman , R.B.; R.E. Andrson ; S.M. Entire and S.B. Hinshberg ( 1980 ) Method of phosphorus determinationm . Clin . Chem. , 26.

Gull, S.D., F.M. Isenberg ,. And H.H. Bryan (1970). Alkaloid toxicology of Solanum-tuberosum. Science, 5: 316.

Hoek, A . E ., A. G. Lemmens, J. W. M. A. Mullink and A. C. Beynen . ( 1988 ) .Influence of dietary calcium:phosphorus ratio on mineral excretion and nephrocalcinosis in female rats . J. of Nutiration . 118: pp. $1210-1216$

Jadhav, S . J .; R . P . Sharma, and D.K . Salunkhe (1981). Naturally occurring toxic alkaloids in foods. Crit. Rev.Toxicol., $9: 21-104$.

Kofranyi , E . and Jekat, F. ( 1964 ) Amino acids determination at Food and Feed . H oppe seyler' s Ztschr., $338,159$.

Meites , S( 1977) .Pediatric Clinical Chemistry , AACC Washington ,pp 146242 .

Morris, S.C. and T.H. Lee (1984). The toxicity and teratogenicity mutagens. Mutat. Res., 89: 95-136.

Oranye , M. and M Rheim , . ( 1951 ) . Microestimation of magniseium in body fluids. J. Bio . Chem ., 189: 379 .

Patil, B.C.; R.P. Sharma; D.K. Salunke and K. Salunkhe (1972). Evaluation of solanine toxicity . Food Cosmet . Toxicol., 10: 395-398.

Renwick , J.H., W.D.B. Claringbold; M.E Earthy; J.D. Few and A.C.S Mclean.(1984). Neural-tube defects produced in Syrian hamsters by potato glycoalkaloids. Teratology, 30: 371-381.

Saleh, M. R., Abd- Elmordy, and G.I. El-Emam (2007). Potato by- products as animal feed. 2- milk production and constituents and their effects on performance of new born lambs in lactating Rahmany ewes. J. Agric. Sci . Mansoura Univ., 32: 4235 - 4245.

SAS (1996). SAS/STAT Guide for personal computer. SAS inst . 


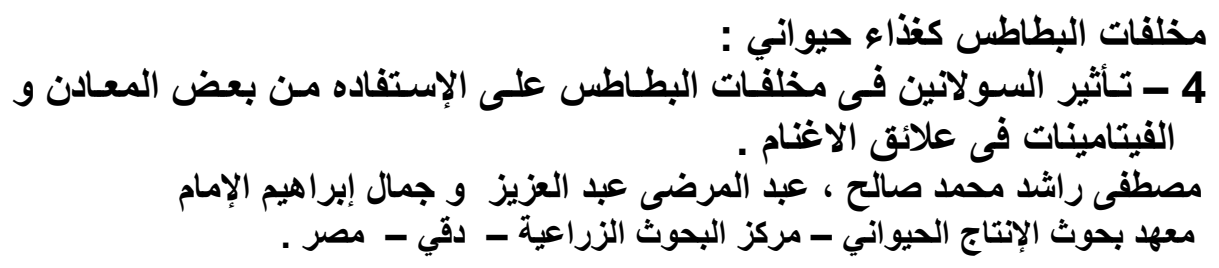

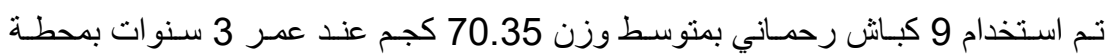

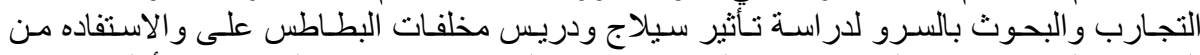

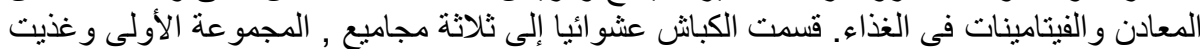

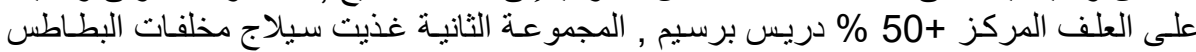

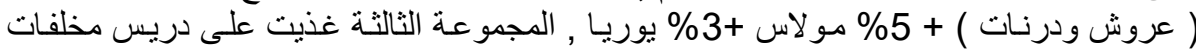

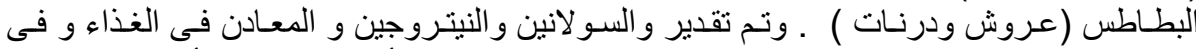

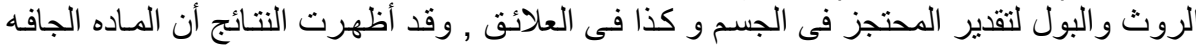

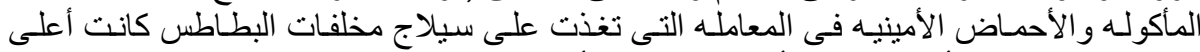

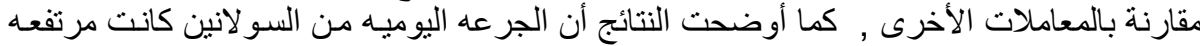

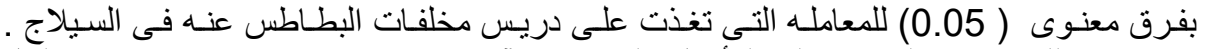

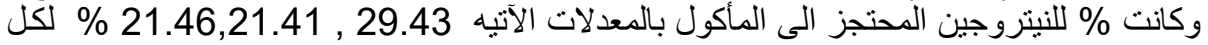

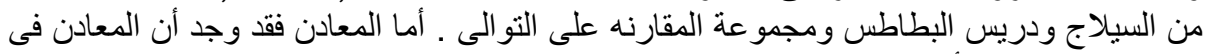

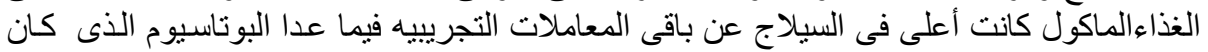

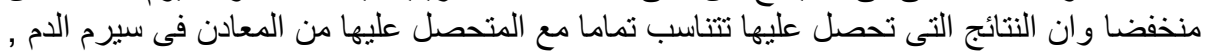

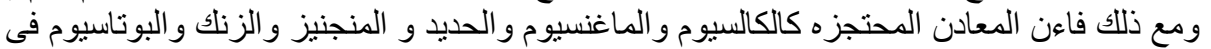

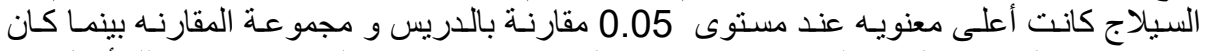

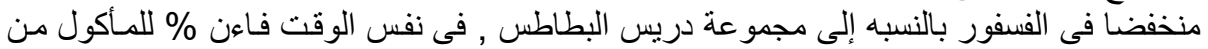

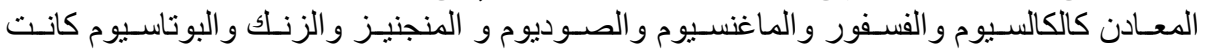

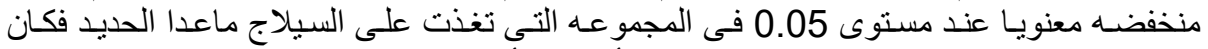

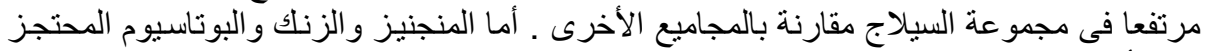

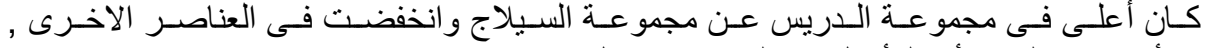

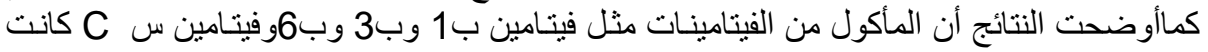

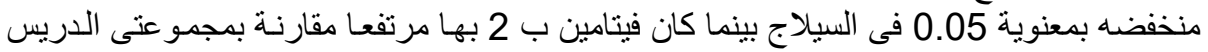

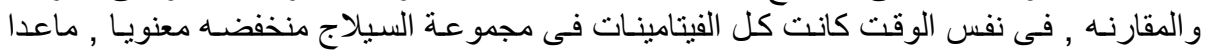

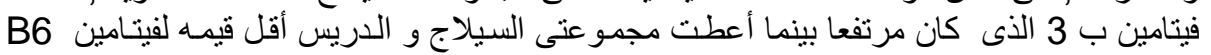
بالنسبه لمجمو عة المقارنه ـ.

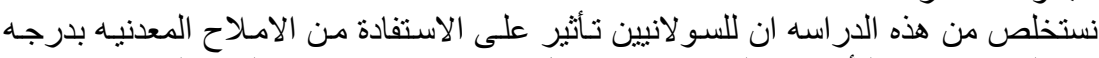

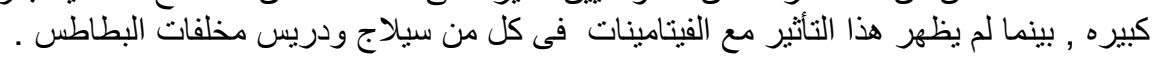

